\title{
Political Dynamics in Regional Legislative Election System to Strengthen Harmonization Political Participation
}

\author{
M. Fadhillah Harnawansyah ${ }^{1, a^{*}}$, Nasrullah Nazsir ${ }^{2}$, Utang Suwaryo ${ }^{2 b}$, and Dede Mariana ${ }^{2}$ \\ ${ }^{1}$ Faculty of Politic and Social Science, Universitas Musi Rawas, Kota Lubuklinggau, Sumatera Selatan 31625, Indonesia \\ 2 Postdoctoral, Universitas Padjadjaran, Bandung, West Java 45363, Indonesia \\ a mfadhillah@fisip-unmura.com; ' utang_59@yahoo.com \\ ${ }^{*}$ Corresponding Author
}

How to Cite : Harmawansyah, M., F., Nazsir, N., Suwaryo, U., Mariana, D. (2019). Political Dynamics in Regional Legislative Election System to Strengthen Harmonization Political Participation. International Journal for Educational and Vocational Studies, 1 (7), 765-772

\section{ARTICLE HISTORY}

Received: 22 August 2019

Revised: 18 September 2019

Accepted: 8 October 2019

\section{KEYWORDS}

Dynamic Politics;

Election System;

Political Representation;

\begin{abstract}
Politics dynamics in regional legislative election system is found the problem there are conditions that are not in harmony between the format election system and the format regional government system. This problem can lead to low political representation of local communities by their legislators. This research contributes to gaining knowledge about the dynamics of regional politics and the ideal electoral system and harmony with local government systems that can be used in the future; with a high level of political representation, and to find out what factors are related to the regional legislative election system. This research uses ethnographic methods through in-depth interviews, direct participant observation, and documentation Data of 5 informants at the home of regional representatives, 5 political parties (in 2 different districts). His findings are that the electoral system still uses a semi-district model that is already out of proportion to the regional government system. Therefore this research is very important to change the improvement of the system which is also supported by a quality, integrity, professional, honest and fair election system; so that it will give birth to regional legislators who have a high level of political representation to their constituents; and at the same time can be effective in the administration of regional government.
\end{abstract}

This is an open access article under the CC-BY-SA license.

\section{INTRODUCTION}

This paper reports on research conducted into the politics dynamics changed the direction of regional electoral system (hereafter referred to as Pilegda). These changes have an impact on disharmony with local government systems that can be used in the future. Other things are also caused by high level of political representation, and to find out what factors are related to the Pilegda system (Yustiningrum and Ichwanuddin, 2014). This system used to choose regional house of representative (DPRD) periodically every five years and they are functioning as executor element of local government. The election of DPRD members is held through regional legislative elections which is as part of implementation of simultaneous Indonesian legislative elections because it is done simultaneously in the entire territories of the unitary republic of Indonesia.

Implementation of Indonesian legislative elections are divided into four Indonesian legislative elections to elect: a) Central house of representative; b)Regional Representative Council of the Republic of Indonesia; c) Provincial regional house of representative; and d) Regency regional house of - representative. The participants of Indonesian legislative elections are the political parties who nominate their candidates of legislative members. Next, nowadays there are many problems, for examples: since the first general election in 1955 up to 2014, the weaknesses of proportional system in Indonesian legislative election (Kartiko, 2014). The evaluation of the general election implementation has already been done. Since the first general election in 1955 to April 9th, 2014, there were many weaknesses and lack in implementation.

In addition, talking about the general election implementation in region, there were problems in relation with "money politics" and "high cost" in this kind of politic which was described by Harris (2005) from several surveys, some polling and researches which have been conducted to the political parties and legislative institution showed the decline in the level of public confidence, especially to the big incumbent parties, both in legislative and executive. Those facts are not only because of decline on public confidence to political parties, but also because of tendency of the increasing problems of money politics in relation with 
legislative-executive, particularly at the local level.

Based on those problems above, it could be seen there were some different problems which became this research focus; the researchers focused on this study to find a harmony system format of Indonesian legislative elections at regions in accordance with system format of local government; this research is expected to have the effect of increasing the level of political representation of the local community showed by their legislators.

However, because of the limitation of time and fund, if this research was conducted more broadly in all regions of Indonesia or some provinces, then researchers would not be able to do it. Therefore, we only focused on comparative studies of system implementation of regional legislative elections at Musi Rawas Regency, Lubuklinggau City and North Musi Rawa Regency because those three regions were closed to the place of researchers so that we could more afford to get data maximally.

Culturally there were differences in ethnicity and race and the level of education among the people of the three regions, so the potential conflicts of differences in implementing a policy, system of government or electoral system could be happened easily. For those reasons, the researchers were very interested to study those problems. Based on those explanations above, this paper tried to formulate the research problems as follow: How do politics dynamics in regional legislative elections have a format harmony with local government in political perspective.

\section{METHODS}

Design and methods qualitative as considerations in this research is required to discuss and collect information and facts from informants, about the dynamics of regional politics and regional legislative elections, specifically concerning discussing the implementation of the regional legislative election system (Pilegda) currently used in Musi Rawas district, Lubuklinggau city, and Musi Rawas Utara district, starting from the process of applying it to the output produced by the system. Data of 5 informants at the home of regional representatives, 5 political parties (in 2 different districts)

Therefore, researchers were required to absorb the views according to the informants themselves by collecting data in the form of detailed stories of informants who expressed what they were, in accordance with the language and views of the informants. To achieve a high level of data validity, the researcher must provide the widest opportunity for informants to explain the phenomena, processes, and impacts of regional political dynamics and the application of the regional legislative electoral system currently in use, so that informants' and aspirations can be revealed complete and holistic, and then processed and analysed systematically and structurally with the studies of political theories, which were able to provide deep, critical, objective, and substantive results of the study.

\section{RESULTS AND DISCUSSION}

\subsection{Approach and Previous Related Studies}

In this research, related to the problems to be discussed, it was about regional political dynamics and system of Indonesian regional legislative election collaborated with local government system, so that it will produce a level of regional community political representation toward their legislators. The researchers in this research will conduct the study by using rational choice approaches and new institutionalism. This was caused the study focus on regional political dynamic and system of regional legislative election that it will be appropriately by using approach method of rational choice thinking and new institutionalism approach because it will study general election commission, assembly at regional level and local government. Theoretically, rational choice theory according to Marsh and Stoker (2002) was: "That when we are faced to several kinds of actions, people usually do what they believe having the best possible result. I will say that rational choice is a set of equipment's which are really needed by experts of political science".

Here, we could know that to study regional political dynamic and Indonesian legislative elections, it will certainly discuss about system, process and institutions, and also problems outside theories which need some approaches of the rational choice theories (Avianto 2014). Then, in the previous related studies, as mentioned before in the background study, there were researchers who conducted the research related to the system of legislative elections, but it was not specifically regional legislative elections. In the previous related studies, as follows: Marzuki (2007) to explore paradigmatic approach the influence of general election system (electoral law) toward political representativeness, especially on the assembly of provincial level, both political representation in formal meaning and political representation in material meaning.

Sukriono (2009) was more specializing on the study about application of general elections systems with the plus and minus, and he also suggested the possibility of the appropriate general election system in Indonesia. The role of general election as an instrument maintain the sovereignty of democracy, by principle of direct, general, free, and confidential (referred to as Luber) and honest and fair (referred to as Jurdil) which in implementation, it was not only determined by electoral process, but also influenced by electoral system itself. More focusing on system implementation of general election on democracy perspective was where this general election system basically related to the how to count votes, calculate votes and share seats (Kartiko, 2014).

Based on previous related studies above, it could be seen clearly that previous researches/studies associated with this research have some similarities, but research focuses were still different in this research. This research was more focused on correlation between regional legislative elections with a level of community political 
representation, and it will be seen from harmonization between regional legislative elections with the current local government system.

\subsection{The political dynamics and regional legislative election}

According to some experts, definition dynamics politics regional was the occurrence of changes and developments in political phenomena that occur in a region and/or regional government. The dynamic of events or political phenomena that occur in the region vary widely ranging from regional elections to regional heads, village head elections, regional legislative election, and so forth. This article will focus only on dynamics regional legislative elections, especially in comparative studies on the implementation of the regional legislative electoral system in Musi Rawas District, Lubuklinggau City and North Musi Rawas Regency; relating to the harmonization of the regional legislative electoral system with the regional government system, and with the level of community political representation towards the legislator.

Many concepts are related to general elections, but a general understanding of the electoral system according to Budiardjo (2008: 461) that in the study of political science various electoral systems have been known with various variations, but in general there are two main principles, namely: a) Single-member Constituency (one electoral district or district area chooses one representative; usually called the District System); b) Multi-member Constituency (one electoral district chooses several representatives; usually called the balanced representative system or the proportional system).

Then the concept of the electoral system was also put forward by Duverger in Grofman and Lijphart (2003:4) the plurality system favors the two-party system, while proportional-system method and the double-ballot system favor multiparty. Proportional representation tends to lead to the formation of many independent parties; (2) The two-ballot majority system tends to lead to the formation of many parties that are allied with each other; (3) The plurality rule tends to produce a two-party system.

In general, the concept of an electoral system known as two main models is the district system (single-member constituency) and proportional system (multi-member constituency). However, there are very different electoral systems used in Indonesia and several countries in the world, namely a mixed system of district systems and proportional systems, namely an open proportional system.

The district system is the oldest electoral system and is based on geographical unity (region), where each geographical unit or region is called a district, because the small area covered then gets a seat in parliament. Where districts are one small area (electoral district) choose a single representative (single-member constituency) with the basic concept of plurality (most votes). Proportional system according to Budiardjo (2008: 462) is a system that divides a large area (electoral district) choosing several representatives (multi-member constituency). The main difference between this system and the district system is how to calculate vote acquisition can produce differences in the composition of representatives in parliament for each political party.

Whereas in Indonesia, using a proportional system with an open list of candidates or an open proportional system is a system for selecting DPR and DPRD members is a system in which the determination of the winner of an election in an electoral district is based on the acquisition of the seat of the political party and the calculation of the results for the legitimate votes of the political party using the voters split number. While the intent of the list of candidates is open, that at the time of nomination, political parties are given the opportunity to determine the names of candidates with the best qualifications as many as the number of seats allocated in the electoral district.

\subsection{The political dynamics and proportional Pilegda}

System of Regional Legislative Election (Pilegda) is a system of elections used to elect members of the regional legislature or in other words members Regional House of Representatives (DPRD) both provincial DPRD and district/city DPRD. The Pilegda system in its implementation remains guided by the basic principles of democracy and the basic principles of elections from the central legislature, namely the People's Representative Council of the Republic of Indonesia (DPR-RI), namely open proportional system. This is done because of the uniformity in the legislative Election system that is used and regulated by the applicable Election legislation.

According to researchers at this time the notion of the regional legislative election system here has the same meaning as the legislative election system above. But the meaning of the word "Region" here has the same meaning as "region" in the regional government. The nature of mind during the French Revolution formulated "gamete" (Autonomous Regions) as "A community alliance that is united by local / regional relations". This formula proposed by Wajong (1975: 8) emphasizes more:

a) There is an environment or region with a border that is smaller than the State;

b) There is a sufficient number of residents;

c) The existence of interests that are difficult to distinguish from those managed by the state, but which are related to the environment, so that the population moves to jointly try on the basis of self-help;

d) The existence of an organization that is sufficient to carry out those interests;

e) The ability to provide the necessary costs.

In fact, the General Election, in accordance with Law number 8 of 2012 concerning general elections in articles 3 and 5 , has the purpose and objectives of its implementation, namely:

a) Select people's representatives who sit in people's representative institutions at the central, provincial 
and regional levels (DPR-RI, Provincial DPRD and Regency / City DPRD).

b) Select people's representatives who sit in regional representative institutions (DPD RI);

c) Establish a democratic, strong government and obtain maximum support from the people (Legitimate); according to Aurel Croissant (in Riswanto, 2016: 1-2).

\subsection{The politic dynamics and political representation}

Conceptually, the meaning of representative government can be expressed from various approaches using various disciplines. The concept of representative government can be explained from the concept "governance relationship" underlying the science of government ontologism (Ndraha, 2003) representative mechanism that is more effective than the population. Given a life (power to on behalf of who is ordered to interact with the government) by constituent, have their own will and from here, their own interests and are bound to the structure. Their behavior changed, it can overthrow the government, can conspire with the government (executive), and can turn against the aspirations of the people that it should represent Riemer (Arfani 1997) (Saragih, 1994). The political representation consists of four types, namely:

a) Type of Trustee, if a people's representative is seen to know what is best for the interests of the nation (region) and the voting community (constituency), and act in harmony with that knowledge and awareness;

b) Type of delegate, people's representatives are seen as representing the interests of their constituents or the voting community. Therefore, in activities in representative institutions, such as giving an opinion or opinion in a trial, the behavior of a representative is determined by what constitutes the interests of his constituents;

c) Type of partisan, is to increase the position and role of political parties in the legislative process as a whole, especially the party's attachment to its ideology which is then known as party discipline;

d) Type of politico, is a combination of the three, meaning that a representative of the people must act on the basis of his/her conscience (conscience), the voting community (constituency), and his/her party (party).

Local political representatives are born as a consequence of decentralization to carry out the functions of local government in accordance with applicable laws and regulations. Regional government or local government can mean as an organ and can also function. As a function local government translated as local government. As an organ, local government often called local authority which includes council or DPRD. local government can also mean as autonomous. In its development, the concept of a government system underwent a shift in which a mixed government system was also known. This is as described by Achmad (2012): mixed government system is an attempt to find a middle ground to take the best from parliamentary and presidential systems. In practice, there are two models of mixed government systems, namely centralization and decentralization. This mixed government system model, for example of those system, there are two states. First, the mixed model of centralization is in the French state; Second, a mixed model of decentralization with the concept of regional autonomy, namely in the country of Indonesia.

\subsection{The politic dynamic and community political representatives}

We have seen that the regional politics in the three research areas have been running quite dynamically, although it is still far from our shared expectations in the effort to build a qualified and responsible democracy. However, if this situation is perceived from the point of view of regional political stability, it is good, where all the legislative elections and regional head elections have been running well, smoothly and peacefully. Moreover, they upheld the principles of elections - direct, general, secret, honest and fair - and, in the same time, included the hope of realizing the election organizers with professionalism and integrity.

a) Voting Model ; On the three research areas, it was seen that the voting model of each voter had no serious constraints and there was no differences in term of the implementation by the General Election Commission (KPU). Indeed, the current model was quite confusing and complicated for low-educated people. Therefore, a more practical method is needed in delivering their votes. The large number of ballot papers that must be chosen by the community is enough to make the public confused in voting. This was because they are not too familiar with the candidates who nominate themselves, especially the number of candidates from each ballot paper. This can be simplified by improving the systems and methods in the central, provincial and district/city legislative elections. Systemically, to reduce the public's confusion, the system was improved by nominating each electoral district with fewer candidates. Then, methodologically, the voting should have started to make modifications and political education for the community to take advantage of information technology, such as the use of electronic voting (e-voting).

b) Electoral District; The indicator of the size of electoral districts is a major factor in the electoral system. Here it is seen whether an election system will go to the district or proportionally. Therefore, the researchers believe that Regional legislative election for the next five years has to make repairs to this electoral district, or in other words, guided by the concept of a semi-district model, namely the electoral district is a sub-district only; This model can produce legislators who have legitimacy of more than 66 percent of the voters' legitimate votes or, in other words, higher than the level of legitimacy in representation in the elections. They impact on increasing the political representation of the community 
towards its legislators.

c) The Making of Representation Restrictions; Restrictions toward the voters and candidates are still needed to meet the needs of government, development and democracy. Therefore, the strengthening of political parties and the regeneration of political parties is needed to increase the capacity and capability of candidates. Global challenges and national and regional needs have always been the main factors in taking consideration of a public policy. This is expected to lead to an increase in the performance of the Regional House of Representatives and the effectiveness of regional government and regional people's welfare.

d. Election Formula Method; The implementation of the election formula model set by the government and KPU is generally valid and similarly executed in the three research locations. Thus, the researchers do not find differences in their application in all three locations. But the researchers found criticism from political actors and the public that the current election formula model needs to be evaluated to be simpler and more efficient and more effective. Here, the researchers propose a change with a pluralistic pattern for each electoral district with the political vote rank in accordance with the number of seats available. In fact, the use of the calculation formula with this SLM model has already led to the process towards the semi-district calculation model. According to the researchers, this should be supported towards a pluralistic model.

e. Threshold Method; The threshold model was not applied in regional legislative election, and this did not make any difference in the implementation of the three study sites. However, the researchers believe that the threshold model for regions with a semi-district system model should be used as a reference in policy and decision making in the election law. This is because there is no parliamentary threshold in the district model since in each electoral district, those who get a seat are only political parties that get the most votes according to the number of seats available.

f. Method for Determining Regional Representatives; The determination model of the number of seats in the Regional House of Representatives and the House of Representatives at this time needs to be readjusted, where the size of the population and the area represented by a legislative member can be a guideline in determining the number of representative seats in an area. Therefore, it is appropriate if this guideline continues based on the total area of the sub-district and the population so that the DPRD members will focus more on their constituents.

Based on the political perceptions of the community in the regional legislative election, it was stated that the regional legislative election system today needs to be continually reformed to go to the regional legislative election system which is more ideal, efficient, and effective in carrying out regional governance. This can be done by changing the regional legislative election system from the open proportional system to the semi-district system. This is certainly expected to bring many advantages in the performance of the DPRD and the political representation of the community, as well as strengthen the system of regional government itself, without forgetting the principles of democracy and the system of regional government.

Relevance of political representation with the effectiveness of the current regional government will be difficult to realize if the model of political representation is still ambiguous with a mixed representation (politico) relationship model between political representation of the community and the very dominant political parties. Moreover, the capabilities and capacities of DPRD members are still below people's expectations and needs in carrying out their duties and functions. The utilization of information technology in politics is appropriate and must be applied by the government and election organizers as soon as possible. As a result, the implementation of elections in Indonesia can be more effective, efficient, accountable, transparent and professional in realizing better democracy in the future.

In general, the effectiveness of regional government can be achieved well if the regional legislative election system is aligned by using a model of political representation that is delegate. This is very possible because this model greatly guarantees the level of political representation of legislators to its constituents is very high. Nevertheless, there is, indeed, a weakening in the representation of political parties.

Regional legislative election system today is considered already quite good but it cannot provide the quality and loyalty of legislators to their constituents or their political party. Therefore, the researchers believe that changing the good and ideal Regional legislative election system will further enhance the political representation of the community by regional legislators, including improving regulations in overcoming weaknesses in human resources and the integrity of candidates in the future. There should be a fairly fundamental change in the election system in order to meet the balance of the system between the regional legislative election system and the regional government system which is guided by level of political representation in the DPRD of which relationship is very high with its constituents, namely with the semi-district Regional legislative election system.

The ideal condition of the regional legislative election system can only be achieved if the regional legislative election system is replaced with a semi-district regional legislative election system. This system means that one electoral district is only one sub-district and the selection formula model is based on the principle of plurality. In addition, this system must be supported by institutional strengthening and work programs of political parties in regeneration, as well as used and compliance of information technology at each stage of regional legislative election. As 
a result, it is expected that implementation regional legislative election system contributes had to improving the political representation and the legislator's performance as people's representatives in their regions.

Politically, as the level of political representation with a relationship model (delegates) is getting higher, it can be proposed that the regional elections can be conducted by parliament only - although this still needs a deeper study. The system of regional house of representatives is not currently harmony with the local government system because the Regional legislative election system is supposed to use the model of semi-districts. By therefore, the change in the Regional legislative election system from proportionally open to the semi-district system must be done by making changes to three things, namely: 1) reducing the electoral area only to one sub-district, 2) doing the votes calculation formula using the principle of plurality, and 3) strengthening the organizational function and cadre of political parties. Then, with the above changes, it must also be supported by the implementation of Regional legislative election that is qualified (professional, honest and fair) and has integrity. As a result, it could give birth to regional legislators who have a good level of political representation to their constituents, as well as being able to provide effectiveness local government.

Furthermore, the unification of regulations integrated between the system of the Regional Government and the Regional House of Representatives election system and the Regional Head election system is a necessity in order to create harmonization of the system which results in a more effective performance of local governments. This must also be supported by the regulation or regulation of the Ministry Affairs, which supports the creation of harmonious rules for improving performance, both by the Regional Government and by the Regional House of Representatives so that the effectiveness of local governments can be effectively achieved.

The results discussion and debate as explained above (see picture 1), then as a solution to answer the problem in this research, there is a concept that can be drawn to operationalize in the field study as a guide in observations and documentation in the future. So, these concepts of changing of regional legislative electoral system that is in harmony with the regional government system, and other systems (such as political systems, party systems, and socio-cultural systems), is a "necessity" so that election effectiveness can be achieved. Then with a harmonious system it is also expected to increase the high level of political representation of the community between legislators and their constituents.

The theoretical suggestions that researchers can recommend in this study can provide insight and development of new concepts in science, particularly in political science about the legislative election areas in Indonesia. It also elaborates how a regional legislative election system has a significant relevance with other systems in the achievement of its effectiveness, particularly the local government system. Meanwhile, the practical suggestions that researchers can recommend are 1) the ideal regional legislative election system for regional government system is semi-district, 2) The Regional House of Representatives is not as mandatory as the House of Representatives, 3) A study needs to be conducted holistically so that it can proceed with the improvement of integrated regulation, ranging from regional legislative system to the local government system, and 4) Semi-district regional legislative election system looks very significant in relation to the current regional government system (regional autonomy). If viewed from the perspective of the high level of representation of the community/constituent politics, it, in turn, will have a positive impact on the performance of Regional House of Representatives. Also, it will also have an impact on the effectiveness of local government (harmony between the Regional legislative election system and the regional government system). Finally, with limited time and other supporting facilities, of course, we are well aware that there are still too many shortcomings in this study. Therefore, constructive suggestions and criticisms as well as further research are highly expected to provide the perfection of this research in the future.

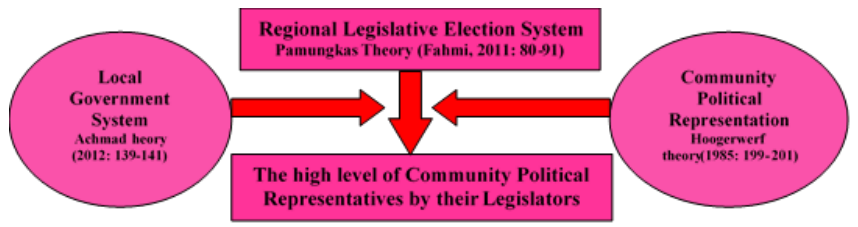

Figure 1. Regional Legislative Election System

\section{CONCLUSION}

The dynamics politics and the regional legislative electoral system had a high level of political representation. The today's election system still needs fundamental changes to meet the system balance between the regional legislative election system with a regional government system. Then, the concept of the regional legislative electoral system had harmonization with the regional government system in a political perspective. In a political review, the current regional legislative election system has not been harmonized with the regional government system, because the Regional legislative election system has not district. Therefore, changes in the Regional legislative election system from proportionally open to semi-district systems must be implemented to achieve a systemic harmony.

The correlation of harmonious relations between the regional legislative election system and the regional government system can be achieved well if the regional legislative electoral system can improve the model of political representation that is delegate or "delegate". This model can be realized if the regional legislative election system uses a semi-district system that greatly guarantees the legislator's level of political representation only to very high constituents. If this system is used for the legislative 
elections, there will be a high level of representation of the regional people by their legislators. Through smart and democratic competitions, the regional house of representatives election will have a position, function and duty as a regional legislature that is intact and balanced with the regional head in the context of strategic partners (check and balance). Meanwhile, to overcome the problem of the interests of political parties against the legislators who are sometimes not in harmony with the vision and mission of political parties, the vision and mission of the political party must adapt to the wishes and aspirations of the people as a whole and integrated. As a consequence, the expectations of the local people are accumulated and are aligned with the vision and mission of the political party itself.

Furthermore, the regional legislative election system used a semi-district model, supported by implementation of quality, integrity and professionalism, as well as being honest and fair; will be able to give birth to regional legislators who have a good level of political representation towards their constituents and political parties; and at the same time able to provide effectiveness in the implementation of regional government.

\section{REFERENCES}

Fauzia, A. A. (2012). State Governance in Political Perspective [Indonesia: Tata Kelola Bernegara dalam Perspektif Politik]. Jakarta: Golden Terayon Press

Amalia, L. S. and Syamsudin, Haris. (2016). Evaluation of the 2014 Legislative Elections: Analysis, Process and results. [Indonesia: Evaluasi Pemilu Legislatif 2014: Analisis, Proses dan Hasil]. Yogyakarta: P2P-LIPI \& Pustaka Pelajar

Arfani, R. N. (1997). Contemporary Indonesian Democracy. [Indonesia: Demokrasi Indonesia Kontemporer]. Jakarta: PT. Raja Grafindo Persada.

Ariyanto, B. (2011). Analysis causes people not voting in the election. [Indonesia: Analisis penyebab masyarakat tidak memilih dalam Pemilu]. Jurnal Ilmu Politik dan Ilmu Pemerintahan Volume 1 No. 1 Tahun 2011, P. 51-60

Asshiddiqie, J., (2014). Concurrent elections and strengthening of the government system [Indonesia: Pemilihan umum serentak dan penguatan sistem pemerintahan]. Vol. 1 No.3

Avianto, BN. (2014). Affective Commitment Apparatus Approach in Regional Marine Programs the Office of Marine, Fisheries, Livestock and Agriculture in Cirebon. [proceeding] https://scholar.google.co.id/scholar?oi=bibs\&cluster=1 7154969458298924987\&btnI=1\&hl=id [09/08/2019] $14: 08$

Bird, R. and Wallich, C. (1993). Fiscal Decentralization and Intergovernment Relation in Transition Economics: Toward a Systemic Frame Work of Analysis
Washington D.C. Policy Research Departement: University of Toronto \& The World Bank

Boeije, H. (2010). Analysis in Qualitative Research.London: Sage Publications

Budiardjo, M. 2005. Dasar-dasar Ilmu Politik. Jakarta: PT. Gramedia Pustaka Utama

Creswell. (2009). Research Design: Qualitative, Quantitative, and Mixed Methods Approaches. Third Edition.Sage Publications. Thousand Oaks. London. New Delhi.

Duverger, M. (1955). Dresst Constitutionnel Institutions Politiques. Paris: Presses Universitaries de France.

Grofman, B. and Lijphart, A. 2003. Electoral Laws and Their Political Consequences. New York: Agathon Press

Holcombe, A., (1910). Direct Primaries and the Second Ballot. American Political Science Review. Vol. 25 No. 27 P. 535-552

Hoogerwerf. (1985). Politikologi. Terjemahan: R. LL. Tobing. Jakarta: Erlangga

Yustiningrum, E. R. R., and Ichwanuddin, W. (2014). Political Participation and Voting Behavior in General Election 2014. Journal of LIPI. Access http://ejournal.lipi.go.id/index.php/jppol/article/downlo ad/533/341. Time: [15:29:00] date: [14/08/2019]

Kartiko, G. (2014). Election System in the Perspective of Democracy in Indonesia. [Indonesia: Sistem Pemilu dalam Perspektif Demokrasi Di Indonesia]. Journal Konstitusi. Access: https://mkri.id/index.php?page=download.EJurnal\&id $=235$ [15:47:11] date: 14/08/2019

Mainwarring, S. and Linz, J. (1997). Presidentialism and Democracy Comparative Politics. Vol. 29. No. 4

Mair, P. (2009). Representative versus Responsible Government. MPIfG Working Paper 09/8. Available at: http://www.mpifg.de/pu/workpap/wp09-8.pdf

Marsh, David and Stoker, Gerry. (2002). Teori dan Metode dalam Ilmu Politik. Bandung: Nusa Media

Marzuki. (2007). The Effect of the General Election System on the Political Representation of the Community in the DPRDs in North Sumatra Province. [Indonesia: Pengaruh Sistem Pemilihan Umum terhadap Keterwakilan Politik Masyarakat pada DPRD-DPRD di Provinsi Sumatera Utara]. Jurnal Disertasi: Pascasarjana Universitas Sumatera Utara.

Mawhood, P., (1983). "Decentralization: The Concept and the Practice", in Mawhood, P. (ed.) Local Government in the Third World. New York: John Wiley \& Sons

Nizam, S., (2015). Menimbang E-Voting pada pemilu legislatif dan pemilu presiden tahun 2019. Disampaikan pada acara seminar laporan akhir kajian strategis tgl 11 Nov 2015. Jakarta: Badan Penelitian dan Pengembangan Kemendagri RI.

Rambe, S., (2015). Alternatif Sistemn Distrik dalam Pemilu 
Indonesia: Upaya Pembangunan Sistem A

Preliminary Analysis. Availableat:

http://www.alternatif_sistem_distrik_dalam_pemilu.p df Tanggal 16/11/2015 11:15

Riwanto, A., (2016). Hukum Partai Politik dan Hukum Pemilu di Indonesia. Yogyakarta: Thafa Media

Saragih, B., R. (1994). Ilmu Negara. Jakarta: Gaya Media Pratama.

Saragih, J.P. (2014). Politics of Fiscal Decentralization: Problems in implementation.[Indonesia: Politik Desentralisasi Fiskal: Permasalahan dalam implementasi]. Jurnal Politicia. Vol:5 No.2. https://jurnal.dpr.go.id/index.php/politica/article/view/ 340. Access: 26 Jul 2019 20:09:08 GMT.

Sukriono, D. (2009). Initiating the electoral system in Indonesia. [Menggagas sistem pemilihan umum di Indonesia]. Jurnal Konstitusi Vol. 2 No. 1. Universitas Kanjuruhan Malang. https://mkri.id/index.php?page=download.EJurnal\&id $=235$ [15:47:11] date: $14 / 08 / 2019$

Shepsle, K. (1989). Studying Institutions: Some Lessons from the Rational Choice Approach. Journal of Theoretical Politics, vol. 1 No. 2 p. 167-182

Haris, S. (2005). Coalition in Indonesia's presidential democratic system: Factors of the fragility of President Yudhoyono's Coalition Era. [Indonesia: Koalisi dalam sistem demokrasi presidensial Indonesia: Faktor faktor Kerapuhan Koalisi Era Presiden Yudhoyono] Jurnal Penelitian Politik. http://ejournal.politik.lipi.go.id/index.php/jpp/article/v iew/473/284. Access: 13 Jul 2019 16:20:07 GMT

Terminassian, T., (1977). "Decentralizing Governement Finance and Government". Vol. 10. No. 3

Wajong, J. (1975). Principles and Objectives of Regional Government. [Indonesia: Azas dan Tujuan Pemerintahan Daerah]. Jakarta: Djambatan

Winardi. (2009). Money politics in elections. [Politik uang dalam pemilihan umum'. Jurnal Konstitusi Vol. 2 No. 1. Universitas Kanjuruhan Malang. https://mkri.id/index.php? page $=$ download. EJurnal\&id=235 $\quad[15: 47: 11]$ date: $14 / 08 / 2019$

Wright, J. F. H. (1980). Mirror of the Nation's Mind: Australia's Electoral Experiments. Sydney: Hale and Iremonger. 